Relations industrielles

Industrial Relations

\title{
The Will and the Way to Negotiate
}

\section{Gérard Tremblay}

Volume 1, numéro 10, juin 1946

URI : https://id.erudit.org/iderudit/1023961ar

DOI : https://doi.org/10.7202/1023961ar

Aller au sommaire du numéro

Éditeur(s)

Département des relations industrielles de l'Université Laval

ISSN

0034-379X (imprimé)

1703-8138 (numérique)

Découvrir la revue

Citer cet article

Tremblay, G. (1946). The Will and the Way to Negotiate. Relations industrielles / Industrial Relations, 1(10), 6-7. https://doi.org/10.7202/1023961ar

Tous droits réservés @ C Département des relations industrielles de l’Université Laval, 1946
Ce document est protégé par la loi sur le droit d'auteur. L’utilisation des services d'Érudit (y compris la reproduction) est assujettie à sa politique d'utilisation que vous pouvez consulter en ligne.

https://apropos.erudit.org/fr/usagers/politique-dutilisation/ 


\section{THE WILL AND THE WAY TO NEGOTIATE}

Since 1944, there is a new trend in labour legislation in Canada.

The passing of federal wartime regulations relating to industrial relations (P.C. 1003) and of the Quebec Labour Relations Act has brought into light the following principles already agreed upon in the public opinion, viz. :

a) that labour organization is for the common good ;

b) that collective bargaining of working conditions must be a compulsory procedure.

We are wondering, however, if employers and employees are really aware of the accrued responsibilities they are now confronted with.

Workers are free to unionize ; the right to organize is clearly protected by the interdiction of anti-labour practices. However, to those who prevail themselves of such right, a corresponding duty is incumbent. Wageearners must organize, but they must develop at the same time a great sense of social responsibility. The individual still remains, but with a mitigated individuality. What he loses of his liberty, he gains in strength by adhering to an active social group. His actions are no longer of individualistic significance : they have a social import conditioned by the importance of the environment. The non-unionized worker who claims a raise of salary for himself and walks out because he has failed to get it, causes but little damage to society. That same worker, if he joins a union and becomes a fluent speaker may bring his fellow-workers to go on strike. His actions go beyond him ; the misuse of his authority over a group may disturb a whole sector of an economic system.

Employers have similar responsibilities. They must not shirk labour lawis, but rather adapt themselves to such laws. Collective bargaining implies the collaboration of both Capital and Labour. An employer's doings have also more than an individualistic character : their import is becoming more and more social. In the field of industrial relations, the employer does not have to deal any more with his employees, but with their delegate. In the latter, he must not see a mere worker, but the representative of a whole factor of production. Psychologically, the attitudes must change. The employer must remember that he can no further indulge in that old freedom of speech and action used in dealing with his employees individually and that he must not forget his manners : one does not treat a group in the same way as an individual.

Employers' and employees' representatives, compelled by law to negotiate in good faith, are aware of the importance, the nature and the particularities of their task. First, they must have the " will" to negotiate. It may seem odd to insist on the factor " will " in collective bargaining. In fact, negotiating is a trying, bitter and irritating thing ; it requires not only intelligence, but comprehensiveness, patience and firmness. It is easier for the employer to say " no " or to impose authoritatively his viewpoint ; on the other hand, the workers' representative will sooner put an end to the discussion and recommend the extreme solution, a strike, if such is not prohibited ; or else, both parties will apply for State conciliation or arbitration : it is so much more convenient and less troublesome! To-day, State intervention is often required to settle the slightest dispute. Do not such repeated requests to the State constitute an abdication of one's responsibilities? Is not the State being robbed of its suppletory action and its authority used to settle trifles? The State must be neither a propagandist nor a business agent ; as already said, it must complete the action of individuals and groups and not serve as their substitute.

It is beneficial to both parties to an agreement to negotiate in good faith. It gives them the opportunity to present their viewpoints, to air their grievances, to make mutual concessions, to get better acquainted and, as a result, to come to a fair settlement.

The will to negotiate is one point, the "know-how " is another. Methods based on theory and experience are now admitted and must be developed. Here are some standards that might be of use to wage-earners' representatives :

1. Democratic formation of the union and of its officers ;

2. The respect of principles and procedures established by the Labour Relations Act ;

3. Careful drafting of the collective agreement, previously approved by the majority of the unionists concerned ;

4. A wise choice of bargaining agents who must be psychologists, intelligent, polite, patient, firm, honest and fully conversent with all techniques pertaining to the industry ;

5. The bargaining agent must also know the following details concerning the industry, such as manufacturing processes ; machinery used ; conditions of hygiene and security; various professional categories; basic wage rates ; incentive premium system ; wages paid in similar industries ; cost of living index ; market conditions;

6. As soon as negotiations are over and the interested parties have reached an agreement acceptable to them both, the workers' delegates must submit this agreement to their fellow-members and try to persuade them to accept it;

7. The workers' representative must not remain neutral as regards a draft agreement he has obtained; he must point out its advantages and disadvantages, but 
must not hesitate to use his influence to have it accepted. The workers' delegate is not only a mandatory but also a leader and a leader must advise, conduct ;

8. A collective agreement may be revised each year ; if it is not perfect, it will then be possible to correct it subsequentely.

On the other hand, the employer cannot undertake negotiating with his employees without being prepared to do so ; therefore, here is our advice to him :

1. Study the laws governing employer-employee relations : you must be familiar with them to discuss them pertinently.

2. Inquire into the living conditions of your employees.

3. Prepare statistics on the average wages earned by the professional categories of your entire staff.

4. Prepare a financial report of your enterprise in case it would become necessary to refer to it.

5. Collect information concerning wage rates paid in similar industries.

6. Never turn down a request; study it, accept it or reject it wholly or partly, with proving arguments, at a subsequent meeting.

7 . If a draft agreement is submitted to you, receive it kindly ; if necessary, prepare a counter-agreement.

8. Your workers are your collaborators; they helped you build your fortune in the past ; be sympathetic to them : it is natural that they want to better their living conditions.

9. Before turning down a request for higher wages, study your enterprise. Is it well organized? Cannot the machinery be modernized? Are the manufacturing processes rationally arranged? Can't you save money? Do you try to find new markets? And what about routine? In brief, your refusal to better working conditions must not be attributed to your deficiencies or your faults.

10. Do not forget that comprehensiveness, politeness and courtesy are always appreciated.

Employers and workers must bear in mind that there is a negotiating technique, that it cannot be improvised, but that it can be acquired through study and practice. If such technique were better known, there would be fewer labour disputes, fewer requests for the State intervention and more social justice.

The Industrial Relations Department of the Faculty of Social Sciences has realized the urgency of its humble collaboration in this field. During the past two years, it has organized, apart from its regular courses, several public lectures, a congress of industrial relations and two intensive courses of two weeks. It will continue in that way where it is certain to be followed by all who want understanding and good faith to prevail in the establishment of sound industrial relations.

Gerard Tremblay.

\section{SUCCES DE LA SESSION INTENSIVE}

La session intensive en relations industrielles organisée en mai dernier par le Service extérieur d'éducation sociale de Laval, en collaboration avec le département des Relations industrielles de la Faculté des Sciences sociales, a remporté, cette année encore, un franc succès. Le programme, un peu différent de celui de l'an dernier mais non moins intéressant, comprenait une quarantaine de cours et quelques forums, de même qu'une visite industrielle. Plus de soixante personnes venues des différents centres de la province ont pris part à cette session ; elles ont, avant leur départ, manifesté leur satisfaction en exprimant le désir que la tenue de telles assises se renouvelle chaque année.

\section{PROCHAIN BULLETIN EN SEPTEMBRE 1946}

Avec le numéro de juin se termine notre première série de Bulletins des relations industrielles. Nous espérons avoir intéressé nos lecteurs, tout en leur rendant service.

Le premier numéro de la deuxième série paraîtra en septembre prochain. Nous profiterons des quelques semaines à venir pour apporter à notre publication certains changements de nature à l'améliorer.

Tous nos lecteurs actuels sont invités à renouveler leur abonnement et à ceux qui désirent compléter la série 1945-46. nous sommes heureux d'annoncer que nous avons maintenant en disponibilité les numéros qui leur manquent.-

\section{RAPPORT DU CONGRĒS}

Le rapport du premier Congrès des relations industrielles de Laval est entre les mains de l'imprimeur et sera prêt pour distribution, nous assure-t-on, vers le 10 juillet. Il contient le texte des conférences qui furent prononcées à cette occasion et dont voici la liste :

$1^{\circ}$ L'Université et les relations industrielles ;

$2^{\circ}$ L'évolution des relations industrielles au Canada ;

$3^{\circ}$ L'apprentissage ;

$4^{\circ}$ Fatigue industrielle et productivité ;

$5^{\circ}$ Conciliation, arbitrage et tribunaux du travail ;

$6^{\circ}$ Les relations industrielles dans l'Etat moderne.

On peut s'en procurer copie moyennant la somme de $\$ 1.00$ et toute correspondance à ce sujet doit être adressée au secrétaire du département des Relations industrielles, Faculté des Sciences sociales, Université Laval, Québec. 